\title{
Food habits of fishes on an exposed sandy beach at Fukiagehama, South-West Kyushu Island, Japan
}

\author{
Yukinori Nakane · Yusuke Suda • Mitsuhiko Sano
}

Received: 26 October 2009/Revised: 29 March 2010/ Accepted: 16 June 2010/Published online: 10 July 2010

(C) Springer-Verlag and AWI 2010

\begin{abstract}
To clarify the feeding habits and major food sources of sandy beach fishes, the gut contents of 55 fish species collected on a sandy beach at Fukiagehama, SouthWest Kyushu Island, Japan, were examined. Ontogenetic changes in food preference were recognized in nine species (Hypoatherina valenciennei, Lateolabrax japonicus, Trachurus japonicus, Sillago japonica, Sphyraena japonica, Paralichthys olivaceus, Heteromycteris japonica, Paraplagusiajaponica, and Takifugu niphobles). A cluster analysis based on dietary overlaps showed that the sandy beach fish assemblage comprised six trophic groups (mysid, amphipod, zooplankton, juvenile fish, terrestrial insect, and mollusk feeders). Of these, the first three groups were the most abundantly represented, whereas the last two were represented by only a single species. These results indicated that epibenthic macrofauna, such as mysids and gammaridean amphipods, and zooplankton, were important food resources for the fish assemblage at the study site, but infaunal macrobenthos, such as polychaetes and bivalves, being relatively unimportant.
\end{abstract}

Keywords Diet - Fish assemblage - Ontogenetic change · Sandy beach $\cdot$ Trophic guild

Communicated by Arne Malzahn.

Y. Nakane $(\bowtie) \cdot$ M. Sano

Department of Ecosystem Studies,

Graduate School of Agricultural and Life Sciences,

The University of Tokyo, 1-1-1 Yayoi,

Bunkyo-ku, Tokyo, Japan

e-mail: anakane@mail.ecc.u-tokyo.ac.jp

Y. Suda

Department of Applied Aquabiology,

National Fisheries University,

2-7-1 Nagata-honmachi, Shimonoseki,

Yamaguchi, Japan

\section{Introduction}

Studies of sandy beach fish assemblages in many parts of the world have indicated that sandy beaches are an important habitat for a number of fishes (Lasiak 1986; Suda et al. 2002; McLachlan and Brown 2006), apparently because sandy beaches provide abundant food and refuges from predation (e.g. McIvor and Odum 1988; Ruiz et al. 1993).

In a review of resource partitioning in fish assemblages, Ross (1986) concluded that trophic separations are generally important in understanding the structure and function of fish assemblages. However, most studies on sandy beach fish assemblages have concentrated on temporal and spatial variations in assemblage structure (Gibson et al. 1993; Clark et al. 1996; Layman 2000; Suda et al. 2002). There is only a limited number of studies on the trophic relationships of sandy beach fishes so far (Robertson and Lenanton 1984; DeLancey 1989; Beyst et al. 1999).

In addition, the predation refuge theory is based on the premise that few piscivorous fishes occur in shallow beach habitats (e.g. Boesch and Turner 1984; Paterson and Whitfield 2000). Recent studies have suggested the importance of small and occasional or 'minor' piscivores such as sparids and small juvenile carangids that are previously overlooked in shallow habitats (Baker and Sheaves 2009 and Sheaves 2001). However, studies on the feeding habits of all species within such an assemblage have rarely been conducted (but see Inoue et al. 2005; Baker and Sheaves 2005). Thus, it is unclear how many piscivore species are in fact present on sandy beaches.

In this study, we examined the patterns of food resource use within a fish assemblage on an exposed sandy beach at Fukiagehama, with the aim of (1) describing the feeding patterns of the fish species within the assemblage and (2) 
identifying the feeding guild structures in the assemblage by determining the degree of dietary overlap among species.

\section{Materials and methods}

\section{Study area}

The study was carried out at Fukiagehama $\left(31^{\circ} 28^{\prime} \mathrm{N}\right.$, $130^{\circ} 18^{\prime} \mathrm{E}$ ), situated on the South-West coast of Kyushu Island, temperate zone of Japan, and opening broadly to the northern part of the East China Sea (Fig. 1). The sandy beach was approximately $45 \mathrm{~km}$ long, with three distinct beach zone represented by different beach types (northernmost zone-reflective beach, southernmost zone-dissipative beach, and middle zone-intermediate beach) (Fig. 1). The dissipative beach was characterized by a wide, low-inclination surf zone across which breaking waves gradually dissipated their force. In contrast, the reflective beach had a relatively steep slope and no surf zone, waves breaking abruptly near the shoreline. The intermediate beach was located between the dissipative and reflective types, being best characterized as a ridge-runnel system.

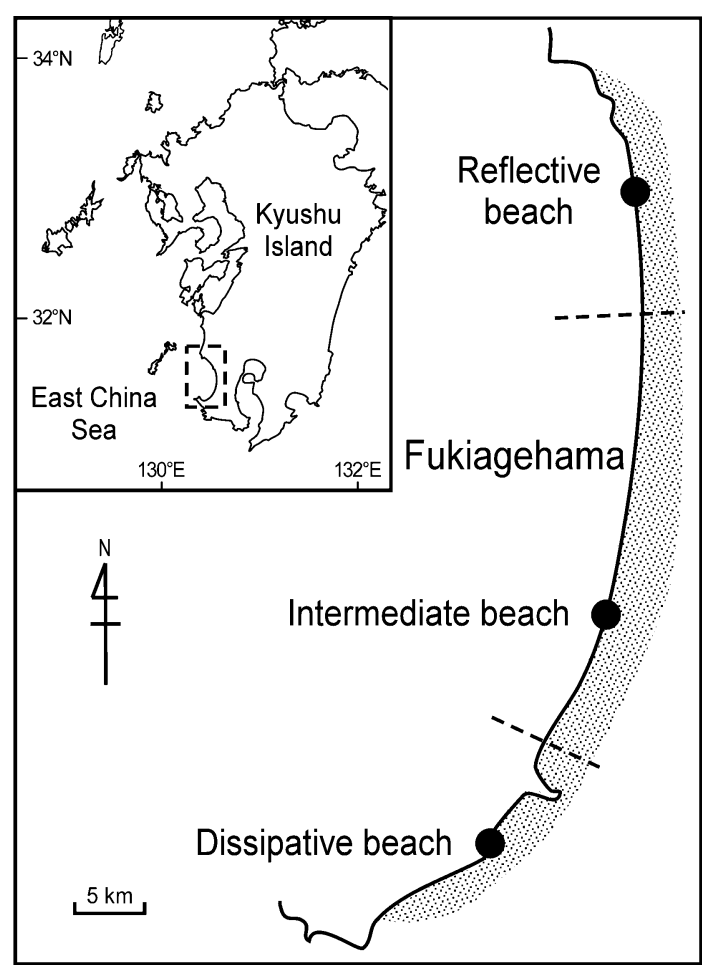

Fig. 1 Map of the sandy beach of Fukiagehama, South-West Kyushu Island, Japan, showing sampling sites (filled black circle) in three coastal segments representing different beach types (reflective, intermediate with a ridge-runnel system, and dissipative)
Fish sampling

Because of the environmental differences among the three beach types, fish were sampled from each using a beach seine net ( $4 \mathrm{~mm}$ square mesh, $16 \mathrm{~m}$ wide and $1.5 \mathrm{~m}$ deep), which was pulled parallel to the shore line in a water depth of approximately $0.5 \mathrm{~m}$. Sampling was conducted at low tide between 0900 and $1600 \mathrm{~h}$ in May, August, and November 2006 and 2007. Each specimen was immobilized on ice immediately after collection. The body cavity was subsequently injected with concentrated formalin and the specimens preserved in $10 \%$ formalin. Very small individuals (too small for injection) were placed directly into $10 \%$ formalin after immobilization. In the laboratory, specimens were identified to species level following Nakabo (2002) and Okiyama (1988) and their standard lengths (SL) measured to the nearest $0.1 \mathrm{~mm}$.

Gut content analysis

A total of 2,357 individuals representing 55 species were examined (Table 1). Some studies have suggested that fewer than five individuals containing food are inadequate for a realistic food item representation of a species (Nakamura et al. 2003; Inoue et al. 2005). However, all species with fewer than five individuals in this study were subjected to gut content analyses because of the value of dietary information for rare species (e.g. Platax boersii and Kuhlia mugil). Food items in the stomach contents or anterior half of the gut (if the fish lack a stomach) of each specimen were identified to the lowest possible taxon, and the percentage volume of each food item in the diet visually estimated under a binocular microscope, as follows: initially, gut contents were squashed on a $1 \mathrm{~mm} \times 1 \mathrm{~mm}$ grid slide to a uniform depth of $1 \mathrm{~mm}$ and the area covered by each item measured. The measured area was then divided by the total area of the gut contents in order to calculate the percentage volume of that item in the diet (Horinouchi and Sano 2000; Kanou et al. 2004). Food resource use was expressed as mean percentage composition of each item by volume, which was calculated by dividing the sum total of the individual volumetric percentage for the item by the number of specimens examined (Sano et al. 1984; Sano 1989). We have compared food habit of each species among different size class after stomach content inspection, and dealing as different size class group if significant difference was recognized by this analysis. Specimens with empty guts $(13.0 \%)$ were excluded from this analysis.

Data analyses

Percentage data of food items of each species were pooled for each year, season, and beach site, because the aim of 
Table 1 Number of specimens and standard length (SL) of each species used for gut content analyses

\begin{tabular}{|c|c|c|c|c|c|c|}
\hline \multirow[t]{2}{*}{ Family } & \multirow[t]{2}{*}{ Species } & \multicolumn{4}{|c|}{ Number of specimens } & \multirow[t]{2}{*}{$\mathrm{SL}(\mathrm{mm}$} \\
\hline & & Reflective & Intermediate & Dissipative & Total & \\
\hline Dasyatidae & Dasyatis akajei & & 1 & 1 & 2 & 250,395 \\
\hline Albulidae & Albula neoguinaica & & 4 & 7 & 11 & $20-28$ \\
\hline Anguillidae & Anguilla japonica & & & 1 & 1 & 118 \\
\hline \multirow[t]{2}{*}{ Clupeidae } & Spratelloides gracilis & & & 2 & 2 & 28,32 \\
\hline & Amblygaster leiogaster & 3 & & & 3 & $27-30$ \\
\hline Engraulidae & Engraulis japonicus & & & 126 & 126 & $24-55$ \\
\hline Chanidae & Chanoschanos & 1 & 2 & 3 & 6 & $29-39$ \\
\hline Plotosidae & Plotosus lineatus & & & 1 & 1 & 154 \\
\hline Synodontidae & Trachinocephalus myops & & & 3 & 3 & $33-38$ \\
\hline Antennariidae & Antennarius striatus & & 1 & & 1 & 17 \\
\hline Syngnathidae & Syngnathus schlegeli & & 1 & & 1 & 85 \\
\hline Mugilidae & Mugil cephalus cephalus & 2 & 20 & 21 & 43 & $17-29$ \\
\hline \multirow[t]{2}{*}{ Atherinidae } & Hypoatherina tsurugae & & 1 & & 1 & 85 \\
\hline & Hypoatherina valenciennei & 11 & 45 & 122 & 178 & $18-97$ \\
\hline Hemiramphidae & Hyporhamphus sajori & & & 19 & 19 & $153-183$ \\
\hline Belonidae & Strongylura anastomella & & 1 & & 1 & 690 \\
\hline Scorpaenidae & Apistus carinatus & 6 & 1 & & 7 & $9-17$ \\
\hline \multirow[t]{2}{*}{ Platycephalidae } & Platycephalus sp. & 2 & 3 & 2 & 7 & $168-500$ \\
\hline & Cociella crocodila & 1 & & 1 & 2 & 66,130 \\
\hline Moronidae & Lateolabrax japonicus & 6 & 11 & 72 & 89 & $22-133$ \\
\hline Scombropidae & Scombrops boops & & 1 & & 1 & 95 \\
\hline \multirow[t]{7}{*}{ Carangidae } & Trachurus japonicus & 1 & 27 & 237 & 265 & $27-79$ \\
\hline & Scomberoides tol & 1 & 5 & 16 & 22 & $24-50$ \\
\hline & Trachinotus baillonii & & 2 & & 2 & 83,105 \\
\hline & Trachinotus blochii & 1 & & 1 & 2 & 85,98 \\
\hline & Caranx sexfasciatus & & & 5 & 5 & $61-88$ \\
\hline & Caranx ignobilis & & 3 & 10 & 13 & $82-112$ \\
\hline & Guathanodon speciosus & 1 & 1 & & 2 & 42,43 \\
\hline Leiognathidae & Leiognathus nuchalis & & & 11 & 11 & $18-25$ \\
\hline \multirow[t]{2}{*}{ Gerridae } & Gerres erythrourus & 1 & & 3 & 4 & $12-13$ \\
\hline & Gerres equulus & & & 21 & 21 & $10-14$ \\
\hline Haemulidae & Plectorhinchus cinctus & 9 & 2 & 7 & 18 & $12-105$ \\
\hline Sparidae & Acanthopagrus latus & & & 2 & 2 & 101,103 \\
\hline Sciaenidae & Nibea mitsukurii & 1 & & & 1 & 15 \\
\hline Sillaginidae & Sillago japonica & 38 & 81 & 774 & 893 & $14-134$ \\
\hline Pomacentridae & Chromis notata notata & & & 1 & 1 & 25 \\
\hline Terapontidae & Terapon jarbua & & & 10 & 10 & $73-86$ \\
\hline Kuhliidae & Kuhlia mugil & 1 & & & 1 & 84 \\
\hline Girellidae & Girella punctata & 2 & 3 & 3 & 8 & $10-23$ \\
\hline Centrolophidae & Psenopsis anomala & 1 & & & 1 & 31 \\
\hline Polynemidae & Polydactylus plebeius & 2 & 3 & & 5 & $30-72$ \\
\hline Percophidae & Matsubaraea fusiforme & & 8 & 10 & 18 & $32-63$ \\
\hline \multirow[t]{2}{*}{ Callionymidae } & Eleutherochir opercularis & & 5 & & 5 & $16-23$ \\
\hline & Repoтисепus lunatus & & & 2 & 2 & 31,45 \\
\hline \multirow[t]{3}{*}{ Gobiidae } & Salangichthys microdon & 13 & 4 & 11 & 28 & $15-45$ \\
\hline & Gymnogobius urotaenia & & 1 & 5 & 6 & $19-25$ \\
\hline & Favonigobius gymnauchen & & & 3 & 3 & $29-59$ \\
\hline
\end{tabular}


Table 1 continued

\begin{tabular}{|c|c|c|c|c|c|c|}
\hline \multirow[t]{2}{*}{ Family } & \multirow[t]{2}{*}{ Species } & \multicolumn{4}{|c|}{ Number of specimens } & \multirow[t]{2}{*}{$\mathrm{SL}(\mathrm{mm})$} \\
\hline & & Reflective & Intermediate & Dissipative & Total & \\
\hline Ephippidae & Platax boersii & & & 1 & 1 & 17 \\
\hline Sphyraenidae & Sphyraena japonica & & 22 & 57 & 79 & $33-67$ \\
\hline \multirow[t]{2}{*}{ Paralichthyidae } & Paralichthys olivaceus & 6 & 15 & 20 & 41 & $26-181$ \\
\hline & Tarphops oligolepis & & 3 & 26 & 29 & $19-65$ \\
\hline Soleidae & Heteromycteris japonica & 1 & 7 & 135 & 143 & $15-96$ \\
\hline \multirow[t]{2}{*}{ Cynoglossidae } & Paraplagusia japonica & 48 & 36 & 21 & 105 & $16-266$ \\
\hline & Arelia bilineata & & & 1 & 1 & 285 \\
\hline Tetraodontidae & Takifugu niphobles & 24 & 63 & 17 & 104 & $15-118$ \\
\hline Total no. individuals & & 183 & 383 & 1,791 & 2,357 & \\
\hline Total no. species & & 25 & 32 & 41 & 55 & \\
\hline
\end{tabular}

Table 2 Gut content components of fishes collected on the sandy beach at Fukiagehama

\begin{tabular}{|c|c|c|}
\hline \multirow{11}{*}{$\begin{array}{l}\text { Table } 2 \text { Gut content } \\
\text { components of fishes collected } \\
\text { on the sandy beach at } \\
\text { Fukiagehama }\end{array}$} & Category & Food item $\left(\operatorname{code}^{\mathrm{a}}\right)$ \\
\hline & Zooplankton & $\begin{array}{l}\text { Calanoid copepods }(\mathrm{Cc}) \text {, Ostracods }(\mathrm{Os}), \text { Harpacticoid } \\
\text { copepods }(\mathrm{Hc}), \text { Unidentified copepods }(\mathrm{Uc}) \text {, Jellyfishes } \\
(\mathrm{Je}), \text { Mysid larvae }(\mathrm{Ml})\end{array}$ \\
\hline & Mysids & Swimming mysids $(\mathrm{Sm})$, Sand-bu rowing mysids $(\mathrm{Bm})$ \\
\hline & Amphipods & $\begin{array}{l}\text { Gammaridean amphipods (Ga), Hyperiidean amphipods } \\
\text { (Hy) }\end{array}$ \\
\hline & Isopods & Isopods (Is) \\
\hline & Decapods & Crabs (Cr), Shrimps (Sh), Callianassids (Ca) \\
\hline & Mollusks & Gastropods (Gp), Bivalves (Bi) \\
\hline & Polychaetes & Polychaetes (Po) \\
\hline & Fishes & Fishes (Fi) \\
\hline & Insects & Terrestrial insects $(\mathrm{Ti})$ \\
\hline & $\begin{array}{l}\text { Others (items regarded as separate } \\
\text { units in the dietary overlap calculation) }\end{array}$ & $\begin{array}{l}\text { Eggs (Eg), Laganins (La), Cumaceans }(\mathrm{Cu}) \text {, Aquatic } \\
\text { plants (Ap), Lepadomorphs (Le) }\end{array}$ \\
\hline
\end{tabular}

a Descriptive codes used in Fig. 2

the study was to describe the feeding patterns of the fish species within the assemblage as a whole. Because of individual size variations in some species, different size classes were examined in order to assess any dietary changes with growth. Since the percentage volume of each major food item in the diet of each species changed rather abruptly at a critical size, the lengths at which such changes occurred were taken as transitional points between size classes. Because the assumption of homogeneity of variance for parametric analysis was not met, even for transformed data, non-parametric Kruskal-Wallis and Mann-Whitney analyses were employed to test whether or not size class differences in the percentage volume of each major food item existed. Nemenyi test was performed when significant differences appeared in the KruskalWallis analyses.

In order to sort the sandy beach fishes into groups that took similar food, dietary overlaps were calculated and a cluster analysis applied. For calculation of dietary overlaps, prey items were grouped in mutually exclusive categories (Table 2). Calculation of the dietary overlap between all species pairs was based on mean percentage volumetric composition of each prey category. For the species with size class differences in feeding habits, each size class was regarded as a separate unit in the analysis. The degree of similarity of fish assemblages among the sites on each sampling occasion was calculated using the Bray-Curtis similarity coefficient, based on the number of individuals of each species. The overlap data were subjected to an average linkage clustering method in order to generate a diet similarity phenogram for the assemblage. This clustering algorithm was used so as not to unduly distort multivariate species (Jaksić and Medel 1990). We arbitrarily adopted a level of $40 \%$ similarity (intermediate overlap value) as a basis for dividing the fishes into feeding groups. 


\section{Results}

Diets

The diets of the 55 species sampled are shown in Fig. 2. Ontogenetic changes in feeding habitat were recognized in nine species: smatran silverside (Hypoatherina valenciennei), Japanese seabass (Lateolabrax japonicus), Japanese jack mackerel (Trachurus japonicus), Japanese sillago (Sillago japonica), Japanese barracuda (Sphyraena japonica), bastard halibut (Paralichthys olivaceus), bamboo sole (Heteromycteris japonica), black cow-tongue (Paraplagusia japonica), and grass puffer (Takifugu niphobles). These ontogenetic changes in the diets are described below for each species. The feeding habits of the remaining species are not dealt with specifically in the text because their dietary composition is included in Fig. 2.

Hypoatherina valenciennei-Smaller fish (18-63 mm SL) consumed predominantly planktonic animals, such as ostracods and calanoid copepods, although their importance decreased significantly in the diet of larger individuals (64$97 \mathrm{~mm}$ SL) (Mann-Whitney analysis, $P<0.001$ for ostracods and calanoid copepods, respectively). Conversely, the contribution of swimming mysids to the diet increased with fish body size (Mann-Whitney analysis, $P<0.001)$.

Lateolabrax japonicus-In the smaller size class (22$112 \mathrm{~mm}$ SL), swimming mysids were the most important food item. Their contribution to the diet decreased with increasing body size (Mann-Whitney analysis, $P<0.001$ ), whereas the percentage volume of juvenile fishes and crabs increased in larger individuals (113-133 mm SL) (MannWhitney analysis $P=0.005$ for fish, $P<0.001$ for crabs).

Trachurus japonicus-The major food item of smaller fish (27-37 mm SL) was harpacticoid copepods but this item decreased in importance in the larger size class $(38-79 \mathrm{~mm}$ SL) (Mann-Whitney analysis, $P<0.001$ ). Conversely, swimming and sand-burrowing mysids became more important with growth (Mann-Whitney analysis, $P<0.001$ for both swimming and sand-burrowing mysids).

Sillago japonica-This species fed on several food categories but their relative importance differed among three size classes (14-23, 24-62, and 83-134 mm SL) (Kruskal-Wallis analysis, $P<0.001$ for each prey item). Smaller individuals (14-23 mm SL) took chiefly planktonic animals, such as ostracods and calanoid copepods, comprising $82 \%$ of the stomach contents by volume, while middle-sized fish (24-62 mm SL) fed mainly on gammaridean amphipods. The contribution to the diet of swimming mysids, shrimps, gammaridean amphipods, polychaetes, and juvenile fishes increased in larger individuals (83-134 mm SL) (Nemenyi test, $P<0.05$ ).

Sphyraena japonica-The diet of the smallest size class (33-38 mm SL) consisted mostly of ostracods but their share decreased with body size (Kruskal-Wallis analysis, $P<0.001)$. Middle-sized individuals (39-41 mm SL) consumed mainly swimming mysids, with larger individuals (46-67 mm SL) taking mostly juvenile fishes, along with swimming mysids (Kruskal-Wallis analysis, $P<0.001$ for swimming mysids, $P=0.003$ for fishes; Nemenyi test, $P<0.05)$.

Paralichthys olivaceus-Swimming mysids constituted the major food of smaller fish (26-105 mm SL) but decreased in importance in larger individuals (109-181 mm SL) (Mann-Whitney analysis, $P<0.001)$. The contribution of juvenile fishes, especially Sillago japonica, increased with body size (Mann-Whitney analysis, $P<0.001$ ).

Heteromycteris japonica-Smaller individuals (15$24 \mathrm{~mm}$ SL) took mostly gammaridean amphipods, whereas the larger size class (25-96 mm SL) fed predominantly on sand-burrowing mysids and mysid larvae. The relative importance of gammaridean amphipods, sand-burrowing mysids, and mysid larvae in the diet differed significantly between the size classes (Mann-Whitney analysis, $P<0.001$ for, gammaridean amphipods and mysid larvae, respectively, $P=0.03$ for sand-burrowing mysids).

Paraplagusia japonica-The diet of the smallest size class (16-50 mm SL) consisted largely of harpacticoid copepods and mysid larvae. However, their relative importance decreased with increasing body size (52-109 and 126-266 mm SL) (Kruskal-Wallis analysis, $P<0.001$ for both harpacticoid copepods and mysid larvae). The largest individuals (52-109 and 126-266 mm SL) fed mainly on gammaridean amphipods, gastropods, swimming mysids, bivalves, and polychaetes (Kruskal-Wallis analysis, $P<0.001$ for gammaridean amphipods, gastropods, swimming mysids, and bivalves $P=0.01$ for polychaetes; Nemenyi test, $P<0.05)$.

Takifugu niphobles-Smaller fish (15-65 mm SL) preyed primarily on gammaridean amphipods and swimming mysids, but the relative importance of these items decreased in the diet of larger individuals (82-118 mm SL) (Kruskal-Wallis analysis, $P<0.001$ for gammaridean amphipods, $P=0.01$ for swimming mysids; Nemenyi test, $P<0.05)$. In the middle- $(69-78 \mathrm{~mm}$ SL) and large- $(82-$ $118 \mathrm{~mm}$ SL) sized classes, on the other hand, the contribution to the diet of juvenile fishes, decapods (such as callianassid shrimps and crabs) and bivalves increased significantly (Kruskal-Wallis analysis, $P<0.001$ for each food item; Nemenyi test, $P<0.05$ ).

Feeding guild

As mentioned earlier, successive changes in food preference by size class were recognized in nine species, each size class of each species therefore being regarded as a separate unit for the cluster analysis. Cluster analysis, 


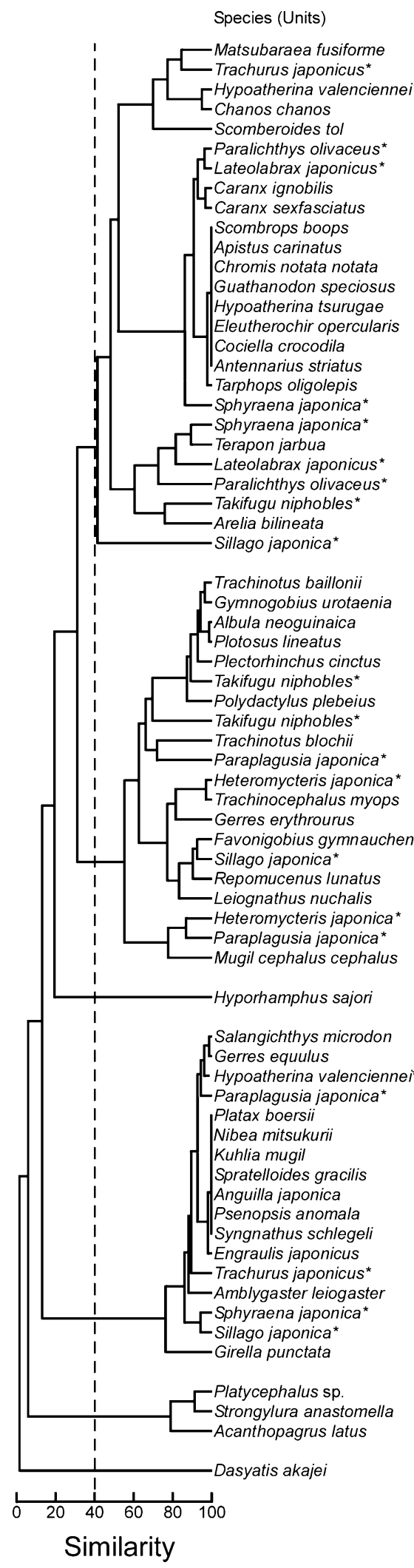

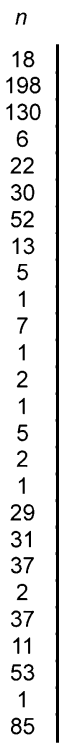

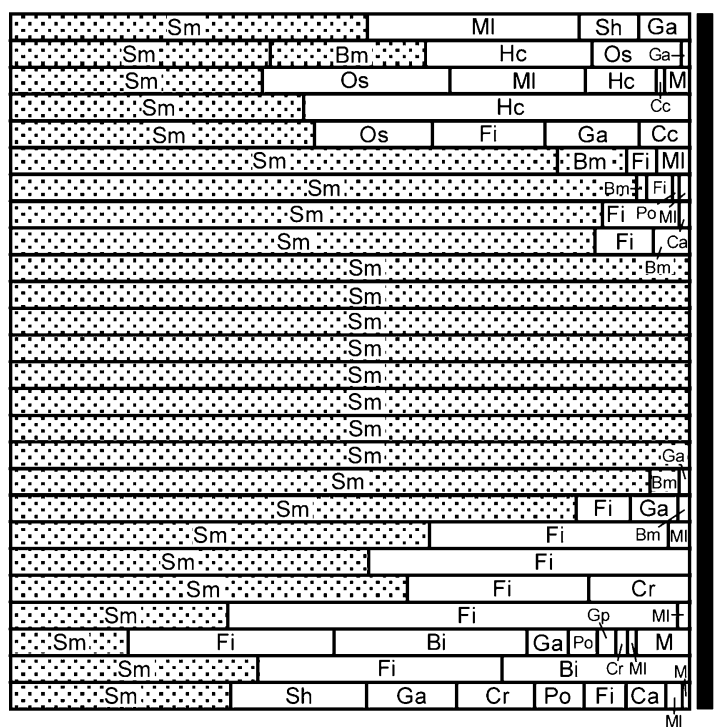

A

B

C

52-183

10-14

18-64

16-52

17
15

15

28,32

118

31

24-55

$27-38$

27-30

33-39

14-24

10-23

$168-500$

690 101, 103

205, 395
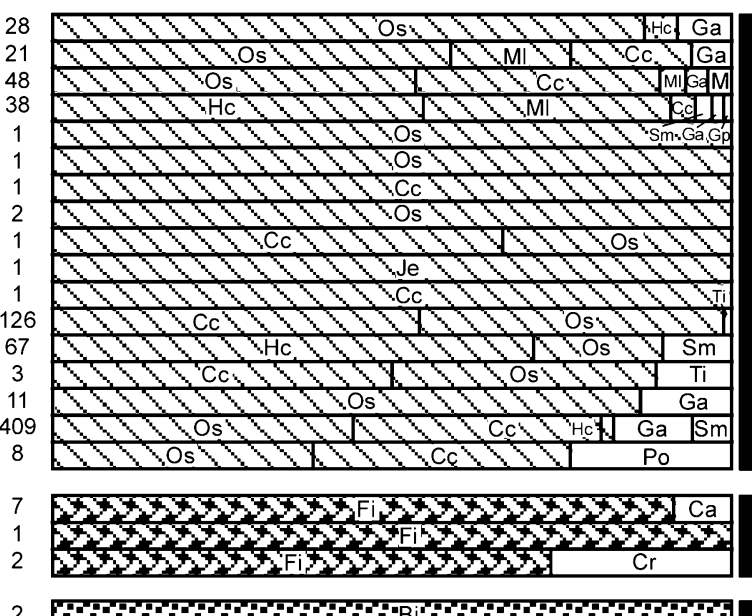

D
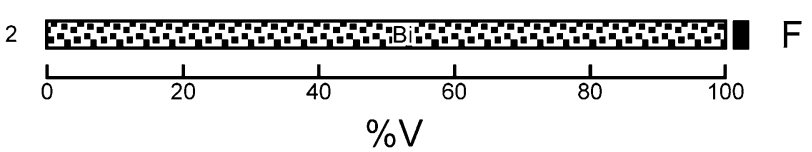

standard length; $n$, number of fish examined containing food. At the $40 \%$ similarity level, the assemblage was divided into six trophic groups: $A$ mysid feeders, $B$ amphipod feeders, $C$ terrestrial insect feeder, $D$ zooplankton feeders, $E$ fish feeders, and $F$ mollusk feeder 
based on the dietary overlap among species, showed that the sandy beach fish assemblage was divided into six trophic guilds at a level of $40 \%$ similarity (Fig. 2).

Mysid feeders (guild A in Fig. 2) comprised 26 species or size groups. Members of this group preyed mostly on swimming mysids (e.g. Acanthomysis nakazatoi and Acanthomysis pseudomitsukurii), sand-burrowing mysids (e.g. Archaeomysis vulgaris and Iiella oshimai) being consumed by only a limited number of species.

Amphipod feeders (guild B) were represented by 20 species or size groups. Although gammaridean amphipods were the most dominant food item, other items, such as swimming mysids, were also important.

Terrestrial insect feeder (guild C) included only one species, Hyporhamphus sajori, which captured primarily terrestrial insects (e.g. ants and dipterans).

Zooplankton feeders (guild D) comprised 17 species or size groups, most of which took mainly calanoid copepods and ostracods. Other items, such as mysid larvae and harpacticoid copepods, were also important for some group members. Zooplankton consumed by this guild was autochthonous.

Fish feeders (guild E) included three species or size groups. All members of this guild exclusively or chiefly captured juvenile fishes, including Engraulis japonicus, Matsubaraea fusiforme, and Sillago japonica, the later species being consumed extensively. Platycephalus sp. and Acanthopagrus latus also took other items, such as callianassid shrimps and crabs.

Mollusk feeder (guild F) was represented by a single species only, Dasyatis akajei, which fed exclusively on venerid bivalves.

\section{Important food}

Based on the cumulative percentage volume values of all fish units for each food item and the percentage of fish units consuming each item, swimming mysids comprised the most important food item for the sandy beach fish assemblage at Fukiagehama (Table 3). Gammaridean amphipods and ostracods were also consumed by many fish units (50 and 29\% of total, respectively), being the second and third most important items by cumulative percentage volume, respectively. Ostracods were largely consumed by small juvenile fishes (e.g. Paraplagusia japonica, Hypoatherina valenciennei, Sillago japonica, and Sphyraena japonica), whereas gammaridean amphipods tended to be taken by larger individuals (e.g. Paraplagusia japonica and Sillago japonica) (Fig. 2). Fishes and calanoid copepods were the fourth and fifth most important items by cumulative percentage volume, respectively, although consumed by about $20 \%$ of the fish units.
Table 3 Cumulative percentage volume $(\% \mathrm{~V})$ for each food item (listed in decreasing order) and percentage of fish units consuming each item $(\% \mathrm{U})$

\begin{tabular}{lcc}
\hline Food items & $\% \mathrm{~V}$ total & $\% \mathrm{U}$ \\
\hline Swimming mysids & 2,362 & 71 \\
Gammaridean amphipods & 1,268 & 50 \\
Ostracods & 910 & 29 \\
Fishes & 577 & 26 \\
Calanoid copepods & 502 & 18 \\
Harpacticoid copepods & 264 & 16 \\
Mysid larvae & 213 & 25 \\
Bivalves & 186 & 9 \\
\hline
\end{tabular}

\section{Discussion}

In general, fish species in the sandy beach study areas had essentially similar diets to those described in other sandy beach habitats. In some species, however, differences in food habits were found between the present and previous studies. For example, Plectorhinchus cinctus (11-55 mm SL) on a sandy beach at Sanrimatsubara, Fukuoka, southern Japan, was recognized as a benthic or epibenthic crustacean feeder, taking mostly mysids (Inoue et al. 2005), and Paraplagusia japonica (56-116 mm SL) on Yanagihama Beach, Nagasaki, southern Japan, fed mainly on copepods (Noichi et al. 1993). At Fukiagehama, however, the major food item of these species, having similar body sizes as those in the aforementioned studies, comprised gammaridean amphipods. Furthermore, ostracods were the most important food item of Sillago japonica (14-24 mm SL) at Fukiagehama, although the species (14-17 mm SL) at Tateyama Bay, Chiba, central Japan, consumed primarily copepods (Arayama et al. 2003). In a sandy beach at Higashihama, Kumamoto, southern Japan, Takifugu niphobles (40-105 mm SL) took mostly callianassid shrimps (Yamahira et al. 1996). In contrast, the present study found that it fed dominantly on gammaridean amphipods, along with swimming mysids. Such food item differences may be partly related to geographic variations, including differences in food availability and/or habitat characteristics (i.e., beach exposure and type) at different locations.

Ontogenetic changes in food preference were recognized in at least nine species, including the four most dominant (Sillago japonica, Trachurus japonicus, Takifugu niphobles, and Hypoatherina valenciennei). Each of these had relatively wide range of fish length compared with other fishes in this study. Such ontogenetic differences in food habits, at least for some species, may be related to increasing gape size with growth, as a greater mouth width enables the capture of longer or larger prey (Checkley 
1982; Schmitt 1986; Boubée and Ward 1997; Lukoschek and McCormick 2001; Kanou et al. 2005). The harder teeth of larger individuals enable the crushing of armored animals, which juveniles are unable to do (Gosline 1971; Wainwright 1988; Horinouchi et al. 1996). Other mechanisms, such as greater catching ability with growth (Horinouchi and Sano 2000), changes in intestinal microbial community (Luczkovich and Stellwag 1993), niche partitioning (Holbrook and Schmitt 1992), and increasing alimentary canal length (Arayama et al. 2003) may also be responsible for such dietary changes.

Fishes collected in this study fell into six trophic groups. Among these, the most abundant feeding guild by unit number was mysid feeders (26 species or size groups). Mysids are known to be extremely common inhabitants on sandy beaches throughout the world (Cockcroft et al. 1988; Takahashi and Kawaguchi 1995; McLachlan and Brown 2006). Lasiak and McLachlan (1987) suggest that opportunistic utilization of such super-abundant prey items may be of immense importance to fishes frequenting highly dynamic environments, such as surf-exposed beaches. In addition to mysid feeders, amphipod feeders (which took predominantly gammaridean amphipods) and zooplankton feeders (which fed mostly on ostracods and calanoid copepods) were the second (20 species or size groups) and third (17 species or size groups) most numerous, respectively. Gammaridean amphipods and zooplankton have also been found to be important food items on other sandy beaches (McFarland 1963; Ross 1986; Inoue et al. 2005), indicating that epibenthic crustaceans (mysids and gammaridean amphipods) and zooplankton are important as food both for the present sandy beach fish assemblage and those on sandy beaches at other geographic locations (Lasiak 1986; McLachlan and Brown 2006). These epibenthic crustaceans and zooplankton are also largely consumed by many fishes in other coastal habitats, including tidal mudflats, reed belts, and seagrass beds (Horinouchi and Sano 2000; Nakamura et al. 2003; Kanou et al. 2004; Horinouchi et al. 2008).

Infaunal macrobenthos, such as polychaetes and mollusks, on the other hand, were important food items for only a limited number of fish species (only Dasyatis akajei) in the present study, the lessened importance of infaunal macrobenthos to fish diets consisting with the findings of a previous study on another temperate sandy beach (Inoue et al. 2005).

On the present sandy beach, only three species (Platycephalus sp., Strongylura anastomella, and Acanthopagrus latus) were fish feeders. However, several small fishes, such as Paralichthys olivaceus, Takifugu niphobles, and Terapon jarbua, often consumed juvenile fish (Fig. 2), although they were not included into the fish feeder guild. Such species may be threat to juvenile and small fish.
In this study, piscivores were hunted mainly juvenile fishes, including Sillago japonica, Engraulis japonicus, Trachurus japonicus, and Matsubaraea fusiforme. This food category, however, was consumed in varying quantities by several species or had a high cumulative percentage volume value (Fig. 2; Table 3). Nakane et al. (2009) found that most juveniles of Sillago japonica used as prey in tethering experiments at the present study beach were consumed within a short time ( $<10 \mathrm{~min})$ of the experiments more commencing. These findings indicate that juvenile fishes comprised one of the more significant food items in the overall diet of the sandy beach fish assemblage.

Acknowledgments We are grateful to J. Ohtomi, Y Hayakawa, and the students of the Laboratory of Coastal Ecosystem Conservation, National Fisheries University, for assistance with fieldwork. Constructive comments on the manuscript from H. Kurokura, J. P. Altamirano, G. Hardy, and anonymous reviewers were much appreciated. This study was funded by the twenty-first Century COE Program 'Biodiversity and Ecosystem Restoration Research Project' of the Ministry of Education, Culture, Sports, Science, and Technology of Japan.

\section{References}

Arayama K, Imai H, Kohno H, Fujita K (2003) Early life history of Japanese whiting Sillago japonica occurring in the surf zone of sandy beaches, Tateyama Bay, central Japan (in Japanese with English abstract). Nippon Suisan Gakkaishi 69:359-367

Baker R, Sheaves M (2005) Redefining the piscivore assemblage of shallow estuarine nursery habitats. Mar Ecol Prog Ser 291:197213

Baker R, Sheaves M (2009) Overlooked small and juvenile piscivores dominate shallow-water estuarine "refuges" in tropical Australia. Estuar Coast Shelf Sci 85:618-625

Beyst B, Cattrijsse A, Mees J (1999) Feeding ecology of juvenile flatfishes of the surf zone of a sandy beach. J Fish Biol 55:11711186

Boesch D, Turner RE (1984) Dependence of fishery species on salt marshes: the role of food and refuge. Estuaries 7:460-468

Boubée JAT, Ward FJ (1997) Mouth gape, food size, and diet of the common smelt Retropinna retropinna (Richardson) in the Waikato River system, North Island, New Zealand. N Z J Mar Freshw Res 31:147-154

Checkley DM Jr (1982) Selective feeding by Atlantic herring (Clupea harengus) larvae on zooplankton in natural assemblages. Mar Ecol Prog Ser 9:243-245

Clark BM, Bennett BA, Lamberth SJ (1996) Factors affecting spatial variability in seine net catches of fish in the surf zone of False Bay, South Africa. Mar Ecol Prog Ser 131:17-34

Cockcroft AC, Webb P, Wooldridge T (1988) Nitrogen regeneration by two surf-zone mysids, Mesopodopsis slabberi and Gastrosaccus psammodytes. Mar Biol 99:75-82

DeLancey LB (1989) Trophic relationship in the surf zone during the summer at Folly Beach, South Carolina. J Coast Res 5:477-488

Gibson RN, Ansell AD, Robb L (1993) Seasonal and annual variations in abundance and species composition of fish and macrocrustacean communities on a Scottish sandy beach. Mar Ecol Prog Ser 98:89-105 
Gosline WA (1971) Functional morphology and classification of teleostean fishes. University Press of Hawaii, Honolulu

Holbrook SJ, Schmitt RJ (1992) Causes and consequences of dietary specialization in surfperches: patch choice and intraspecific competition. Ecology 73:402-412

Horinouchi M, Sano M (2000) Food habits of fishes in a Zostera marina bed at Aburatsbo, central Japan. Ichthyol Res 47:163173

Horinouchi M, Sano M, Taniuchi T, Shimizu M (1996) Stomach contents of the tetraodontid fish, Takifugu pardalis, in Zostera beds at Aburatsubo, central Japan. Ichthyol Res 43:455-458

Horinouchi M, Kume G, Yamaguchi A, Toda K, Kurata K (2008) Food habits of small fishes in a common reed Phragmites australis belt in Lake Shinji, Shimane, Japan. Ichthyol Res 55:207-217

Inoue T, Suda Y, Sano M (2005) Food habits of fishes in the surf zone of a sandy beach at Sanrimatsubara, Fukuoka Prefecture, Japan. Ichthyol Res 52:9-14

Jaksić FM, Medel RG (1990) Objective recognition of guilds: testing for statistically significant species clusters. Oecologia 82:87-92

Kanou K, Sano M, Kohno H (2004) Food habits of fishes on unvegetated tidal mudflats in Tokyo Bay, central Japan. Fish Sci 70:978-987

Kanou K, Sano M, Kohno H (2005) Ontogenetic diet shift, feeding rhythm, and daily ration of juvenile yellowfin goby Acanthogobius flavimanus on a tidal mudflat in the Tama River estuary, central Japan. Ichthyol Res 52:319-324

Lasiak TA (1986) Juveniles, food and the surf zone habitat: implications for teleost nursery areas. S Afr J Zool 21:51-56

Lasiak TA, McLachlan A (1987) Opportunistic utilization of mysid shoals by surf-zone teleosts. Mar Ecol Prog Ser 37:1-7

Layman CA (2000) Fish assemblage structure of the shallow ocean surf-zone on the eastern shore of Virginia Barrier Islands. Estuar Coast Shelf Sci 51:201-213

Luczkovich JJ, Stellwag EG (1993) Isolation of cellulolytic microbes from the intestinal tract of the pinfish, Lagodon rhomboides: size-related changes in diet and microbial abundance. Mar Biol 116:381-388

Lukoschek V, McCormick MI (2001) Ontogeny of diet changes in a tropical benthic carnivorous fish, Parupeneus barberinus (Mullidae): relationship between foraging behavior, habitat use, jaw size, and prey selection. Mar Biol 138:1099-1113

McFarland WN (1963) Seasonal change in the number and the biomass of fishes from the surf at Mustang Island, Texas. Publ Inst Mar Sci Texas 9:91-105

McIvor CC, Odum WE (1988) Food, predation risk, and microhabitat selection in a marsh fish assemblage. Ecology 69:1341-1351

McLachlan A, Brown AC (2006) The ecology of sandy shore, 2nd edn. Academic Press, Burlington

Nakabo T (ed) (2002) Fishes of Japan with pictorial keys to the species, English edn. Tokai University Press, Tokyo
Nakamura Y, Horinouchi M, Nakai T, Sano M (2003) Food habitats of fishes in a seagrass bed on a fringing coral reef at Iriomote Island, southern Japan. Ichthyol Res 50:15-22

Nakane Y, Suda Y, Hayakawa Y, Ohtomi J, Sano M (2009) Predation pressure for a juvenile fish on an exposed sandy beach: comparison among beach types using tethering experiments. La mer 46:109-115

Noichi T, Kusano M, Ueki D, Senta T (1993) Feeding habit of fishes eating settled larval and juvenile Japanese flounder (Paralichthys olivaceus) at Yanagihama Beach, Nagasaki Prefecture (in Japanese with English abstract). Bull Fac Fish Nagasaki Univ $73: 1-6$

Okiyama M (ed) (1988) An atlas of the early stage fishes in Japan. Tokai University Press, Tokyo

Paterson AW, Whitfield AK (2000) Do shallow-water habitats function as refugia for juvenile fishes? Estuar Coast Shelf Sci 51:359-364

Robertson AI, Lenanton RCJ (1984) Fish community structure and food chain dynamics in the surf-zone of sandy beaches: the role of detached macrophyte detritus. J Exp Mar Biol Ecol 84:265283

Ross ST (1986) Resource partitioning in fish assemblages: a review of field studies. Copeia 2:352-388

Ruiz GM, Hines AH, Posey MH (1993) Shallow water as a refuge habitat for fish and crustaceans in non-vegetated estuaries: an example from Chesapeake Bay. Mar Ecol Prog Ser 99:1-16

Sano M (1989) Feeding habits of Japanese butterflyfishes (Chaetodontidae). Environ Biol Fish 25:195-203

Sano M, Shimizu M, Nose Y (1984) Food habits of teleostean reef fishes in Okinawa Island, southern Japan. Mus Univ Tokyo Bull 25:1-128

Schmitt PD (1986) Feeding by larvae of Hypoatherina tropicalis (Pisces: Atherinidae) and its relation to prey availability in One Tree Lagoon, Great Barrier Reef, Australia. Environ Biol Fish 16:79-94

Sheaves M (2001) Are there really few piscivorous fishes in shallow estuarine habitats? Mar Ecol Prog Ser 222:279-290

Suda Y, Inoue T, Uchida H (2002) Fish communities in the surf zone of a protected sandy beach at Doigahama, Yamaguchi Prefecture, Japan. Estuar Coast Shelf Sci 55:81-96

Takahashi K, Kawaguchi K (1995) Inter- and intraspecific zonation in three species of sand-burrowing mysids, Archaeom ysis kokuboi, A. grebnitzkii, and Jiella ohshimai, in Otsuchi Bay, northeastern Japan. Mar Ecol Prog Ser 116:75-84

Wainwright PC (1988) Morphology and ecology: functional basis of feeding constraints in Caribbean labrid fishes. Ecology 69:635645

Yamahira K, Kikuchi T, Nojima S (1996) Age specific food utilization and spatial distribution of the puffer, Takifugu nipobules, over an intertidal sand flat. Environ Biol Fish 45:311-318 